\title{
EXPERIMENTAL STUDIES ON THE IMPACT OF CHANGING THE PIPE MATERIAL ON THE PROPAGATION OF THE PRESSURE WAVE DURING WATER HAMMER
}

\author{
Natalia Krystyna Gietka ${ }^{\varpi}$ \\ Faculty of Civil and Environmental Engineering, Gdańsk University of Technology, Gabriela Narutowicza 11/12, 80-233 Gdańsk
}

\begin{abstract}
Aim of the paper is to present the results studying the water hammer phenomenon in pipes made of different materials, and to show the impact of changing the type of material of the pipe on the velocity of the pressure wave during the transient flow in the pipes. In terms of research material and methods, pipes made of galvanized steel and high-density polyethylene were tested. Measurements were made using strain gauges with a high accuracy of measurement. The results of the pressure wave velocity range from 205 to $247 \mathrm{~m} / \mathrm{s}$ for the polyethylene pipe, and from 426 to $1351 \mathrm{~m} / \mathrm{s}$ for the steel pipe. Therefore, the change in the type of the pipe material has a significant effect on the velocity of the pressure wave during the water hammer. The value of this velocity is influenced not only by the properties of the material itself or of the liquid, but also of the length of the sections and their position relative to each other. It is evident that the velocity in the polyethylene pipe does not change significantly in relation to the situation where the pipe has constant material characteristics. The situation is radically different in the case of a steel pipe, where the velocity of the pressure wave changes along with the length of the pipe and its position relative to the tank. The lowest value of the velocity in the elastic pipe is achieved when the latter is on the valve side and is only $13.15 \mathrm{~m}$ long, while the highest value is reached when the $13.24 \mathrm{~m}$ steel pipe is located on the side of the tank.
\end{abstract}

Keywords: water hammer, velocity of the pressure wave, material of the pipe, elastic pipe, viscoelastic pipe

\section{INTRODUCTION}

The phenomenon of water hammer involves rapid changes in the pressure and speed in the pressure pipe. It may be caused, for example, by sudden closing of the valve or sudden shutdown of the pumps. The said phenomenon can occur both in sanitary installations and in industrial pipelines. The pressure wave that arises in the pipeline during the phenomenon moves at a velocity, the value of which depends both on the properties of the liquid flowing in the pipe and the properties of the material from which the pipe is made. The pressure wave propagation process itself is relatively well rec- ognized in the case of homogeneous pipes, i.e. pipes having fixed dimensions and constant material characteristics. However, in practice, situations when a pipeline or a network of pipelines consists of pipes made of various materials are increasingly common. In such instances, the pressure wave propagates in particular pipes with variable velocity, significantly affecting the course of pressure oscillation. The changes concern not only the extreme values, which are important from the point of view of designing the installation to safeguard it against the phenomenon of water hammer. Likewise, the rate of pressure oscillation damping also changes. The method of changing the parameters of

区e-mail: natgietk@pg.edu.pl 
the pressure wave depends primarily on the mutual proportions of the lengths of individual pipeline sections made of different materials, as well as their relative position.

The phenomenon of water hammer has been the subject of research for over two hundred years. Nevertheless, despite the development of knowledge regarding this issue as well as the progress in the field of measurement technology that enable pressure measurement in pipelines, not all problems have yet been identified. For this reason, the issue of transient flow in pipelines, in situations where pipe material changes, requires detailed research. Previous attempts have been made to undertake this type of research, but they were not exhaustive. They were aimed at identifying the phenomenon itself, and at assessing the suitability of the method of reflection and transformation to simulate the phenomenon of water hammer (Chorzewski, 1999; Mitosek, Chorzelski 2001, 2002). The work of pipelines constructed by connecting pipes of different diameters, but with the same velocity of the pressure wave propagation, was also studied (Mitosek and Malesińska, 2000). It was found that the classic approach to analysing this phenomenon does not fully explain the reasons for damping and smoothing the pressure wave occurring in the pipeline during the water hammer (Mitosek and Kodura, 2000). For example, it still remains unexplained how the individual factors causing dissipation of energy affect the process of propagation of the pressure wave during transient flow in the pipes under pressure. Another serious problem appeared in the case of viscoelastic pipes. It is necessary to consider their specific properties, which are not taken into account in the classic approach, although they essentially change the course of the water hammer phenomenon. Until now, in the construction of the installation and the network, elastic materials have been used such as steel for which Hooke's law applies, while the behaviour of plastics depends on time and mechanical stress history. The impact of these properties on the process of pressure wave propagation has been discussed, among others, by Covas et al. (2005), Weinerowska-Bords (2006) and other authors. The variability of the pressure wave velocity itself has been tested for elastic pipes (Szymkiewicz and Mitosek, 2016). It was observed that depending on the length of the pipe connected to the tank, the velocity of the pressure wave in the tankpipe system changes, and the longer the pipe is, the closer the value of the wave speed is to the value determined for the pipe that is not connected to the tank.

This paper presents the results of experimental research conducted on a test bench for measuring transient flow in a straight pipeline. The research aims to show the impact of changing the type of material on the velocity of the pressure wave created during the phenomenon of water hammer. The practical aspect of the work is related to the operation of a network of pipelines consisting of sections with different material characteristics. This is a typical situation in the case of water supply networks, which when extended and modernized receive additions of pipes made of various materials. The result is a change in the value of maximum pressure, as well as the place and time of its occurrence.

\section{DESCRIPTION OF THE TEST BENCH}

Empirical data were obtained on the test bench located in the Hydraulic Laboratory of the Faculty of Civil and Environmental Engineering of the Gdańsk University of Technology (see: Fig. 1 and Fig. 2). While studying the water hammer phenomenon, eight measurement series were made, where for each of the series the test bench was remodelled, and the location of the pipes relative to the tank changed, as did the length of the pipes. The first two series were performed on the test bench shown in Figure 1. For further research, the test bench underwent a modification presented in Figure 2.

The measurements were performed for high density polyethylene (PE-HD 80) pipes with an outer diameter of $20 \mathrm{~mm}$ and a wall thickness of $2 \mathrm{~mm}$, and galvanized steel pipes with an outer diameter of $21.3 \mathrm{~mm}$ and a wall thickness of $2.6 \mathrm{~mm}$. In the connection of the above-mentioned pipes, thanks to the use of a special nipple, there is no change in the inner diameter of the pipes, so that there will be no local loss of mechanical energy. In all of the eight measurement series, the total length of the tested pipeline was $52.32 \mathrm{~m}$.

In order to determine the water velocity in the pipe in steady-state flow, a flow meter and water meters at the end and at the beginning of the test bench were 


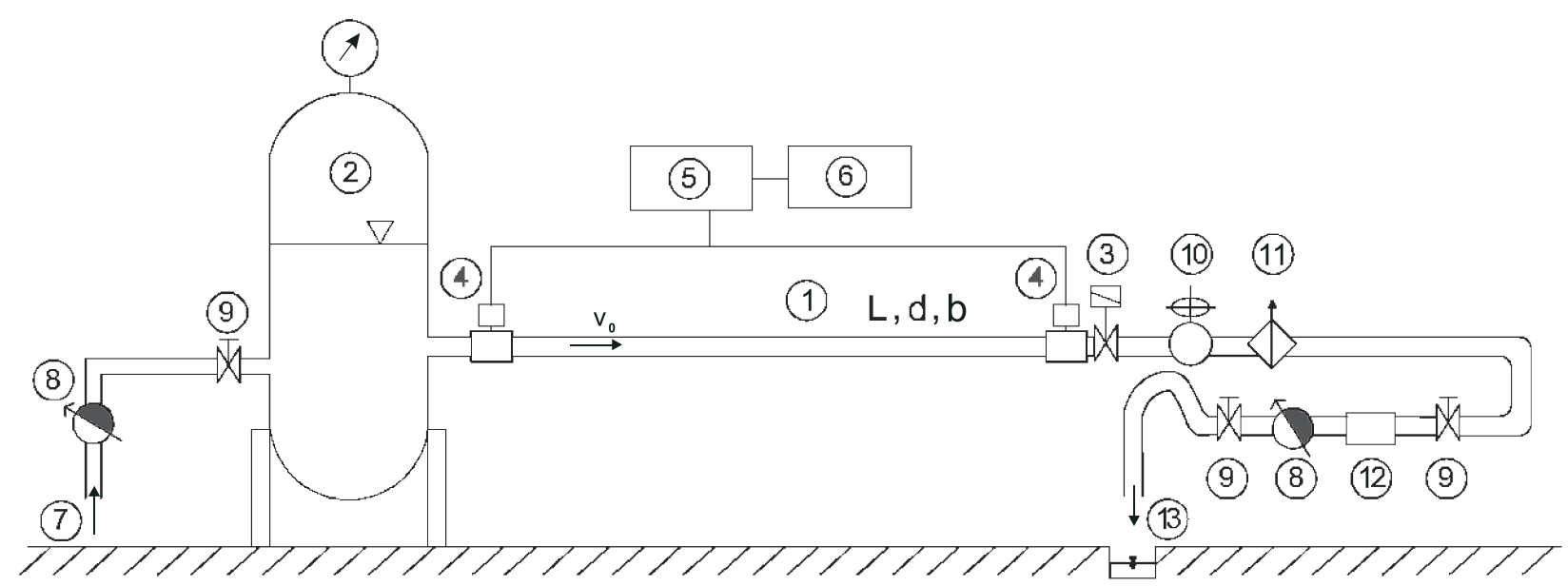

Fig. 1. Schematic of the test bench for pipe made from one material: 1 - pipe, 2 - closed pressure tank, 3 - off valve, 4 - strain-gauge pressure sensor, 5 - extensometer amplifier, 6 - computer with AD/DA card, 7 - supply pipe, 8 - wing water-meter, 9 - off valve, 10 - water hammer silencer, 11 - degasser, 12 - electromagnetic flow-meter, 13 - outflow, $v_{0}$ - velocity at steady flow, $L$ - pipe length, $d$ - pipe nominal diameter, $b$ - pipe wall thickness

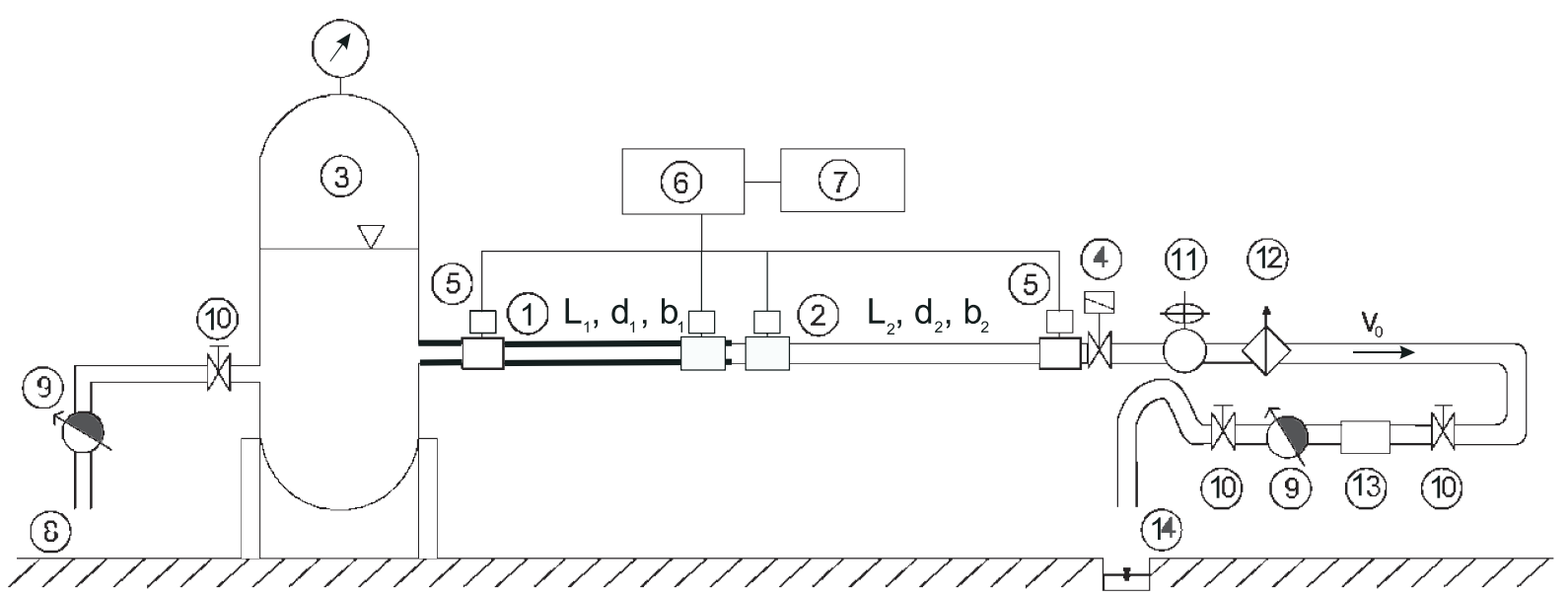

Fig. 2. Schematic of the test bench for pipe made from two materials: 1 - first pipe, 2 - second pipe, 3 - closed pressure tank, 4 - electromagnetic valve or off valve, 5 - strain-gauge pressure sensor, 6 - extensometer amplifier, 7 - computer with $\mathrm{AD} / \mathrm{DA}$ card, 8 - supply pipe, 9 - wing water-meter, 10 - off valve, 11 - water hammer silencer, 12 - degasser, 13 - electromagnetic flow-meter, 14 - outflow, $v_{0}$ - velocity at steady flow, $L_{1}$ - first pipe length, $d_{1}$ - first pipe nominal diameter, $b_{1}$ - first pipe wall thickness, $c_{1}$ - velocity for pressure wave in the first pipe, $L_{2}-$ second pipe length, $d_{2}-$ second pipe nominal diameter, $b_{2}$ - second pipe wall thickness, $c_{2}$ - velocity for pressure wave in the second pipe

used. In turn, for measuring the pressure in the tank, a pressure gauge was used that was standard equipment installed in the pressure tank.

The measurement of pressure in transient flow was carried out by means of four absolute pressure strain-gauge sensors with a maximum working range of 1.2 MPa or 2.5 MPa. During measurements on the test bench shown in Figure 1, strain-gauge pressure sensors were placed in the following locations: at the end of the pipe - just before the valve, at the $3 / 4$ of the 
length of the pipe, at half the length of the pipe, and at $1 / 4$ of the length of the pipe. In turn, during measurements on the test bench shown in Figure 2, one of the sensors was always at the end of the pipe - just before the valve, the second before the change in the material of the pipe, the third after the change in the material of the pipe, and the fourth in the vicinity of the tank. Such location of the sensors made it possible to determine the velocity of the pressure wave in individual sections of the pipe made of non-homogeneous material. All the experiments we conducted concerned a simple water hammer.

\section{IMPACT OF MATERIAL CHANGE ON THE PERTINENT FORMULAS}

The classic set of equations for hydraulic shock (water hammer) (Wylie and Streeter, 1987), derived from the principles of the conservation of mass and the conservation of momentum for elastic pipelines, consists of the following:

- continuity equation:

$$
\frac{\partial H}{\partial t}+v \frac{\partial H}{\partial x}+\frac{c^{2}}{g} \frac{\partial v}{\partial x}=0
$$

- dynamic equation:

$$
\frac{\partial v}{\partial t}+v \frac{\partial v}{\partial x}+g \frac{\partial H}{\partial x}+\frac{\lambda}{2 d}|v|^{2}=0
$$

However, in the case of pipes with viscoelastic properties, it is necessary to account for the latter. This fact changes the equation of continuity. As a consequence, the set of water hammer equations takes the following form (Covas et al., 2005):

- continuity equation:

$$
\frac{\partial H}{\partial t}+v \frac{\partial H}{\partial x}+\frac{c^{2}}{g} \frac{\partial v}{\partial x}+\frac{2 c^{2}}{g} \sum_{i=1}^{N} \frac{\partial \varepsilon_{i}}{\partial t}=0
$$

- dynamic equation:

$$
\frac{\partial v}{\partial t}+v \frac{\partial v}{\partial x}+g \frac{\partial H}{\partial x}+\frac{\lambda}{2 d}|v|^{2}=0
$$

where:

$\mathrm{d}$ - inner diameter of the pipe, $\mathrm{m}$;

$\mathrm{g}$ - standard gravity, $\mathrm{m} \cdot \mathrm{s}^{-2}$;

$\mathrm{H}$ - pressure in the pipeline, $\mathrm{m}$;

$t$ - time, s;

$v$ - average velocity in the pipeline section, $\mathrm{m} \cdot \mathrm{s}^{-1}$;

$x$ - location, $\mathrm{m}$;

$\lambda$ - coefficient of resistance along the length calculated as for steady-state flow, -;

$\varepsilon_{i}-$ strain (deformation) of the i-th Kelvin-Voigt element, $\mathrm{m} \cdot \mathrm{m}^{-1}$;

$c$ - wave celerity, $\mathrm{m} \cdot \mathrm{s}^{-1}$, determined from the formula:

$$
c=\sqrt{\frac{K / \rho}{1+(K \cdot d / E \cdot b) \cdot \beta}}
$$

where:

$b$ - thickness of the pipe wall, m;

E - Young's modulus of the material of the pipe (modulus of elasticity), Pa;

$K$ - modulus of elasticity of liquid (bulk modulus), $\mathrm{Pa}$;

$\rho$ - fluid density, $\mathrm{kg} \cdot \mathrm{m}^{-3}$;

$\beta$ - coefficient accounting for the method of fastening the pipe, - .

In order to determine the strain (deformation), a modified Kelvin-Voigt model is used, which consists of a mechanical spring model and Kelvin-Voig $\mathrm{N}$-elements, that is, a parallel circuit of two mechanical models, i.e. a spring and a piston. Momentary strain of the spring $\varepsilon_{s}$ and retarded deformation of the spring connected in parallel with the piston $\varepsilon_{o}$ is calculated using the following formula (Weinerowska-Bords, 2015):

$$
\begin{aligned}
\varepsilon & =\varepsilon_{s}+\varepsilon_{o}=\frac{\gamma \cdot \beta \cdot d}{2 \cdot b \cdot E_{0}}\left[H(x, t)-H_{0}(x)\right]+ \\
& +\sum_{i=1}^{N} \frac{\gamma \cdot \beta \cdot d}{2 \cdot b \cdot E_{i}}\left[H(x, t)-H_{0}(x)\right]\left[1-e^{-t / \tau_{i}}\right]
\end{aligned}
$$

The above equation makes it possible to determine strain (deformation) at constant stress. In the problem under discussion, stress is variable over time, therefore 
it is necessary to account for this fact in the formula. Assuming that the material of the pipe is homogeneous and isotropic, and that the Poisson ratio is constant, the total deformation of the viscoelastic pipe can ultimately be recorded as follows:

$$
\begin{aligned}
\varepsilon(t) & =\frac{\gamma \cdot \beta \cdot d}{2 \cdot b \cdot E_{0}}\left[H(x, t)-H_{0}(x)\right]+ \\
& +\sum_{i=1}^{N} \frac{1}{E_{i} \cdot \tau_{i}} \int_{0}^{t} \frac{\gamma \cdot \beta \cdot d}{2 \cdot b}\left[H(x, t-\xi)-H_{0}\right] \cdot e^{-\xi / \tau_{i}} d \xi
\end{aligned}
$$

where:

$$
\begin{aligned}
\gamma & - \text { bulk density of the liquid, } \mathrm{N} \cdot \mathrm{m}^{-3} ; \\
E_{0} & \text { Young's modulus of the spring, Pa; } \\
E_{i}- & \text { Young's modulus of the i-th Kelvin-Voigt } \\
& \text { element, Pa; } \\
\tau_{i}- & \text { retardation time of the i-th Kelvin-Voigt ele- } \\
& \text { ment, } \mathrm{s} \text {; } \\
H_{0}- & \text { pressure level in steady conditions, } \mathrm{m} ; \\
H- & \text { pressure height at time } t, \mathrm{~m} ; \\
\xi- & \text { variable of integration, }-.
\end{aligned}
$$

The sets of equations presented above can be solved using numerical methods. However, it should be remembered that pipe material change causes a variable velocity of pressure wave propagation in individual sections, and this requires the introduction of calculations into the algorithm: the so-called compliance conditions at the connection point of the pipe sections (see: Fig. 3). These conditions result from rules, operating in conjunction. Flow continuity principle results in the following condition:

$$
\frac{\pi d_{i}^{2}}{4} \cdot v_{i}=\frac{\pi d_{j}^{2}}{4} \cdot v_{j}
$$

whereas the principle of energy conservation, excluding local losses, produces the following condition:

$$
H_{i}=H_{j}
$$

Taking into account the above conditions makes it possible to solve equations (3) and (4) and (5) and (6) in pipes with different properties.



Fig. 3. Schematic of the connection pipes with different properties

\section{MEASUREMENT RESULTS}

Below, there are shown the results of pressure measurements during transient flow in a pressurized pipe, which were made for the absolute pressure in the tank at fixed conditions: $H_{0}=50 \mathrm{~m}$, velocity $v_{0}=0.4 \mathrm{~m} \cdot \mathrm{s}^{-1}$ and average water temperature $T=12{ }^{\circ} \mathrm{C}$. Figures 3 and 4 present the results of pressure measurements for pipes made of homogeneous material. For the series of measurements in which the tested pipe consists of two different materials, only two exemplary situations are presented: first, when the tested pipeline consists in half of plastic, and in the other half of steel (viewed from the valve) (see: Fig. 6), and second, when the tested pipeline also consists of these two materials in halves, but in a reverse sequence (see: Fig. 7).

When analysing the variation of pressure during the water hammer for pipes made of non-homogeneous materials, we notice that the pipe connections do not affect the value of the pressure, since its distribution in the sensors before and after the connection does not change. This leads to the conclusion that both the connection itself and the choice of the diameter of the pipes are correct. When observing the course of pressure variation over time, it can be noticed that at the point where the pipes are connected, the velocity of the pressure wave propagation changes, and at the same time a partial reflection of the wave occurs, which causes the phenomenon of wave overlap to occur. The change in the velocity of the pressure wave results from a change in the pipe's material's properties. In the elastic pipe, the velocity of the pressure wave is much higher than in the case of the viscoelastic pipe. Therefore, when the steel pipe is located on the side of the valve that causes the phenomenon of water hammer, a much faster progression of the phenomenon is observed, and the effects of wave overlap are visible much more clearly. 
a)

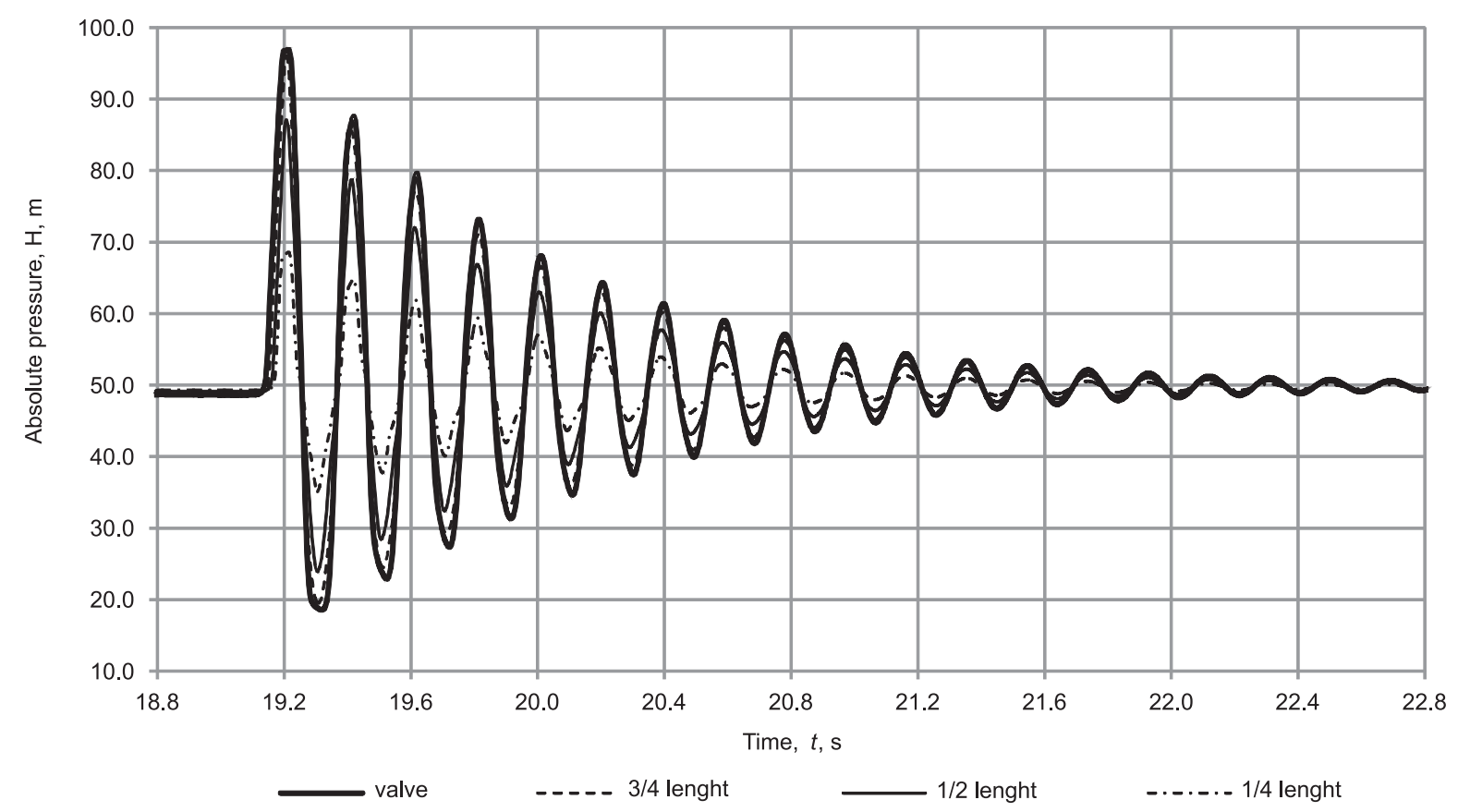

b)

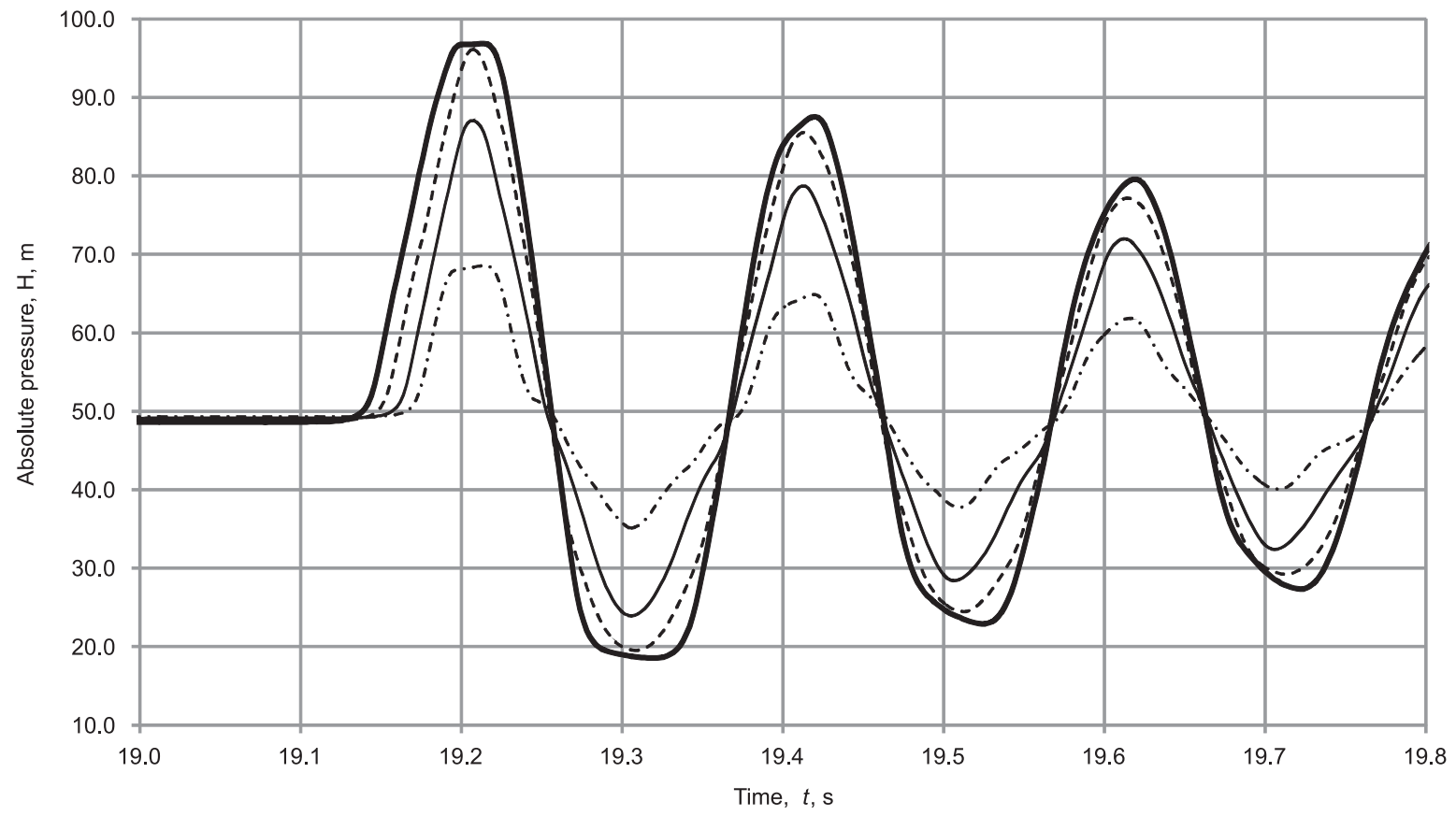

Fig. 4. Pressure variability during the transient pipe flow in the steel pipe with the length $L=52.32 \mathrm{~m}$, outer diameter $d_{1}=21.3 \mathrm{~mm}$, wall thickness $b_{1}=2,6 \mathrm{~mm}$, at an initial pressure of $H_{0}=0.5 \cdot 10^{6} \mathrm{~Pa}$, and an initial speed of $v_{0}=0.4 \mathrm{~m} \cdot \mathrm{s}^{-1}$ 
Gietka, N.K. (2019). Experimental studies on the impact of changing the pipe material on the propagation of the pressure wave during water hammer. Acta Sci. Pol., Formatio Circumiectus, 18(1), 15-26. DOI: http://dx.doi.org/10.15576/ASP.FC/2019.18.1.15

a)



b)

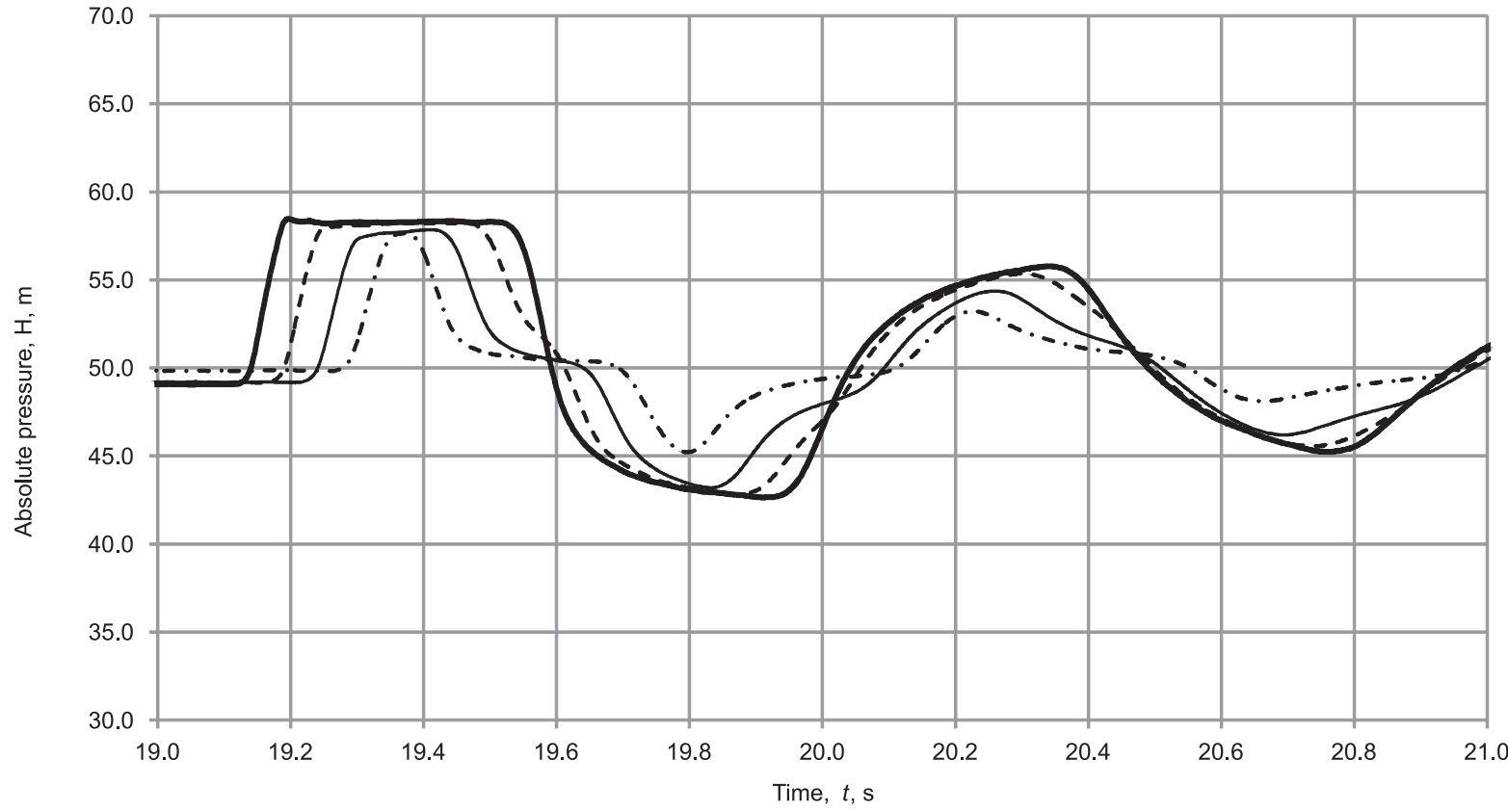

Fig. 5. Pressure variability during the transient pipe flow in the polyethylene pipe with the length of $L=52.32 \mathrm{~m}$, outer diameter $d_{2}=20 \mathrm{~mm}$, wall thickness $b_{2}=2 \mathrm{~mm}$, at an initial pressure of $H_{0}=0.5 \cdot 10^{6} \mathrm{~Pa}$, and an initial speed of $v_{0}=0.4 \mathrm{~m} \cdot \mathrm{s}^{-1}$ 
Gietka, N.K. (2019). Experimental studies on the impact of changing the pipe material on the propagation of the pressure wave during water hammer. Acta Sci. Pol., Formatio Circumiectus, 18(1), 15-26. DOI: http://dx.doi.org/10.15576/ASP.FC/2019.18.1.15

a)

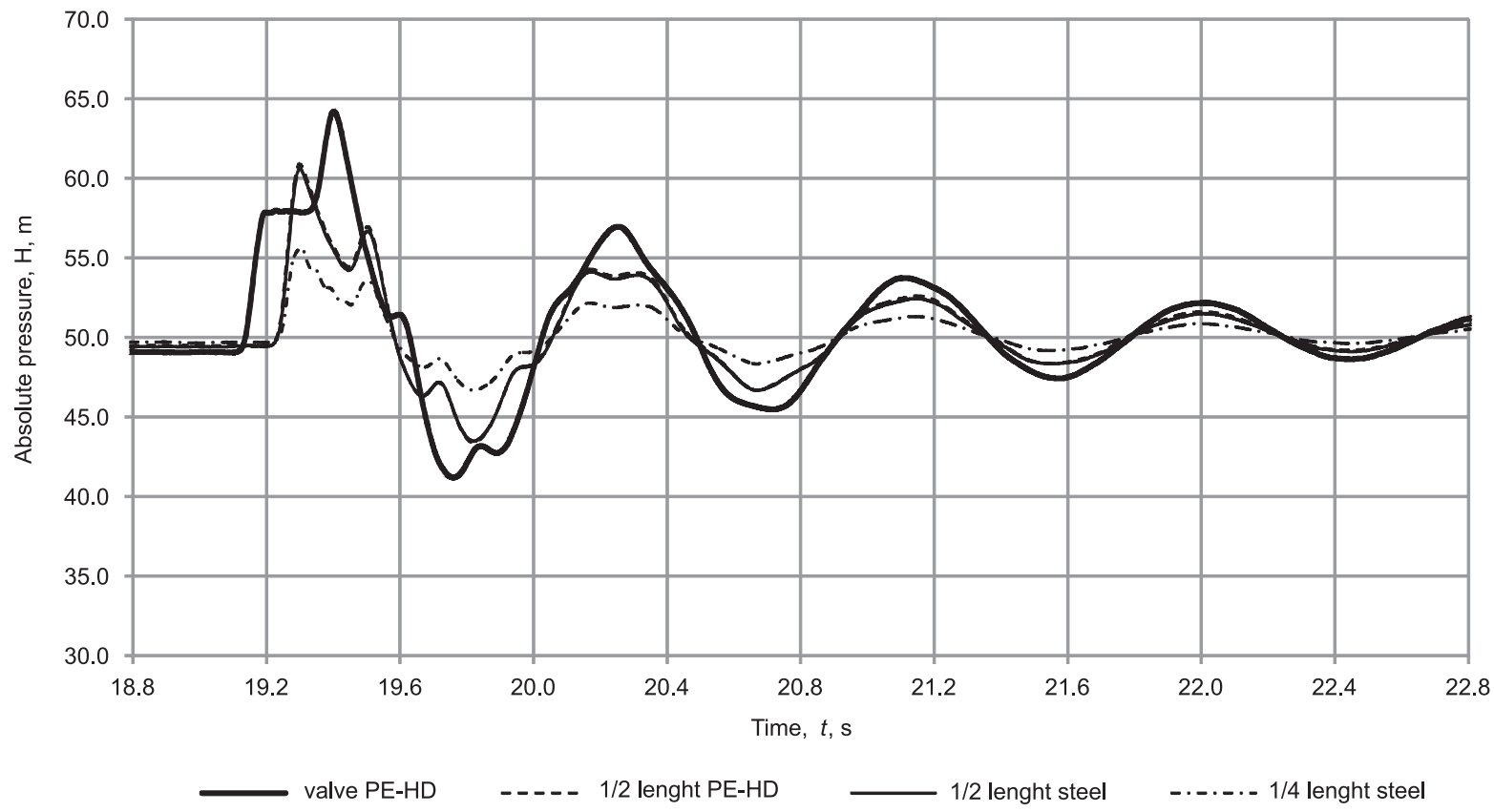

b)

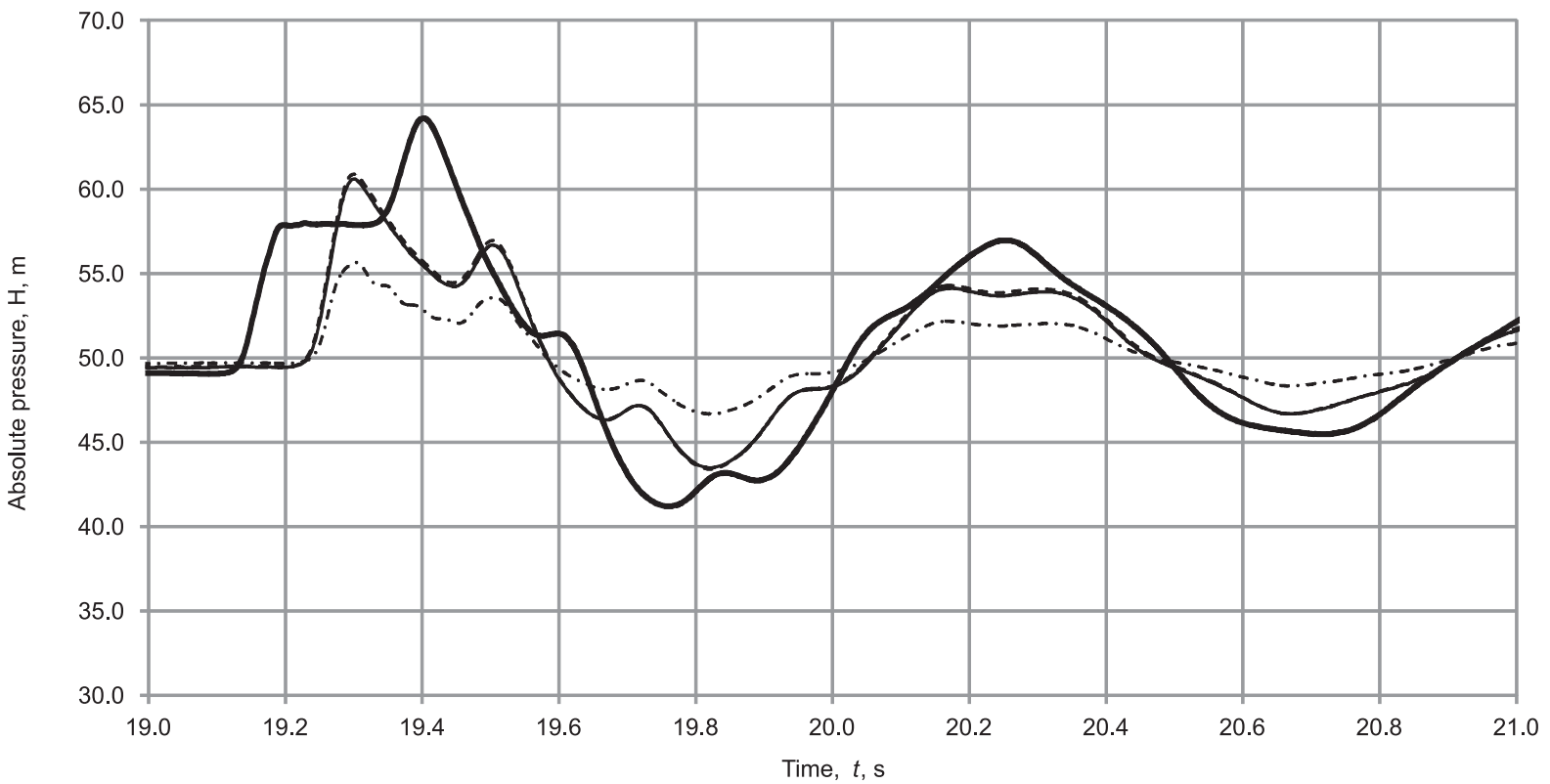

Fig. 6. Pressure variability during the transient pipe flow in pipe made of half of galvanized steel and half of high-density polyethylene with total length $L=52.32 \mathrm{~m}$, at an initial pressure of $H_{0}=0.5 \cdot 10^{6} \mathrm{~Pa}$, and an initial speed of $v_{0}=0.4 \mathrm{~m} \cdot \mathrm{s}^{-1}$ 
a)

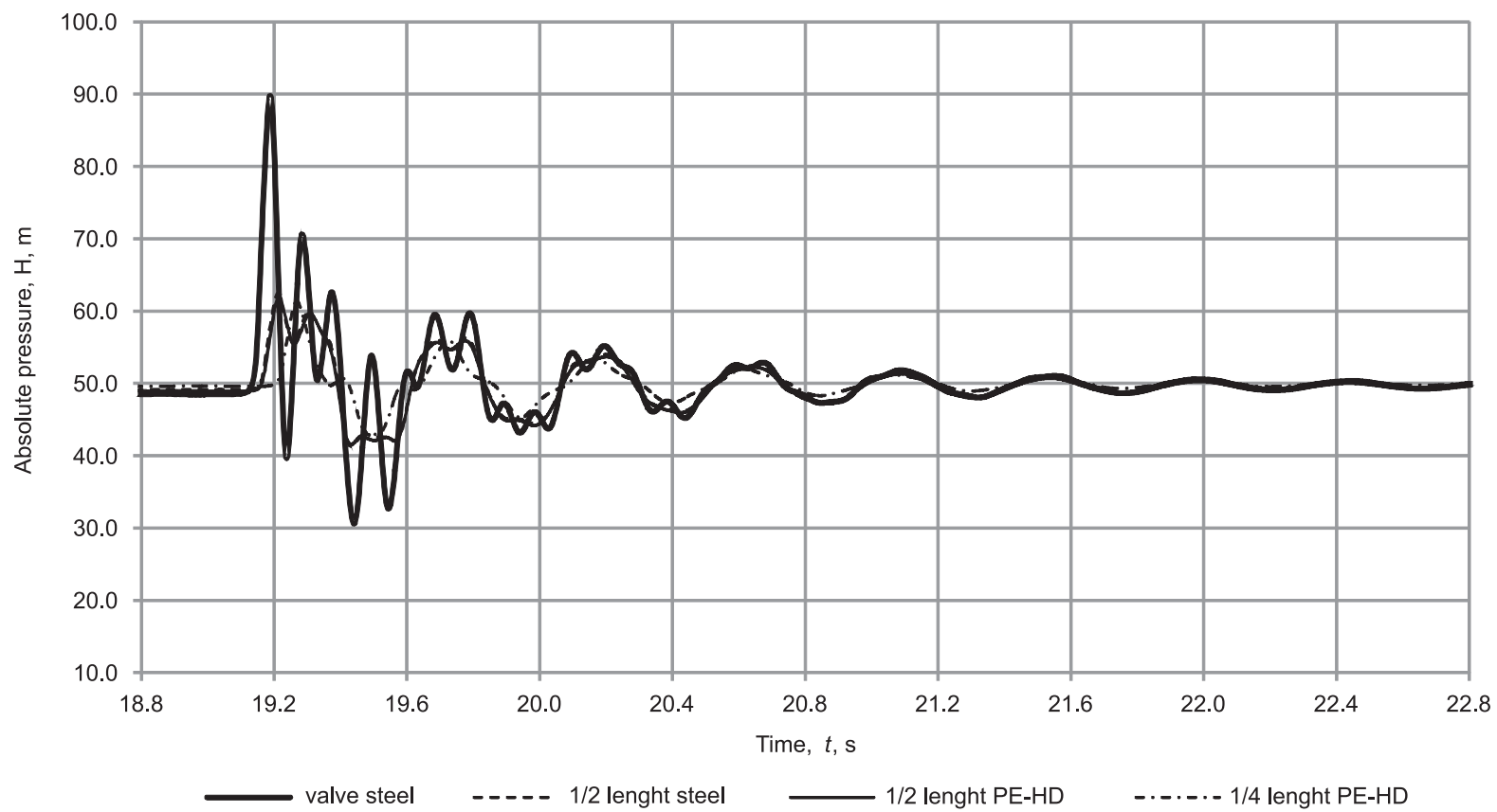

b)

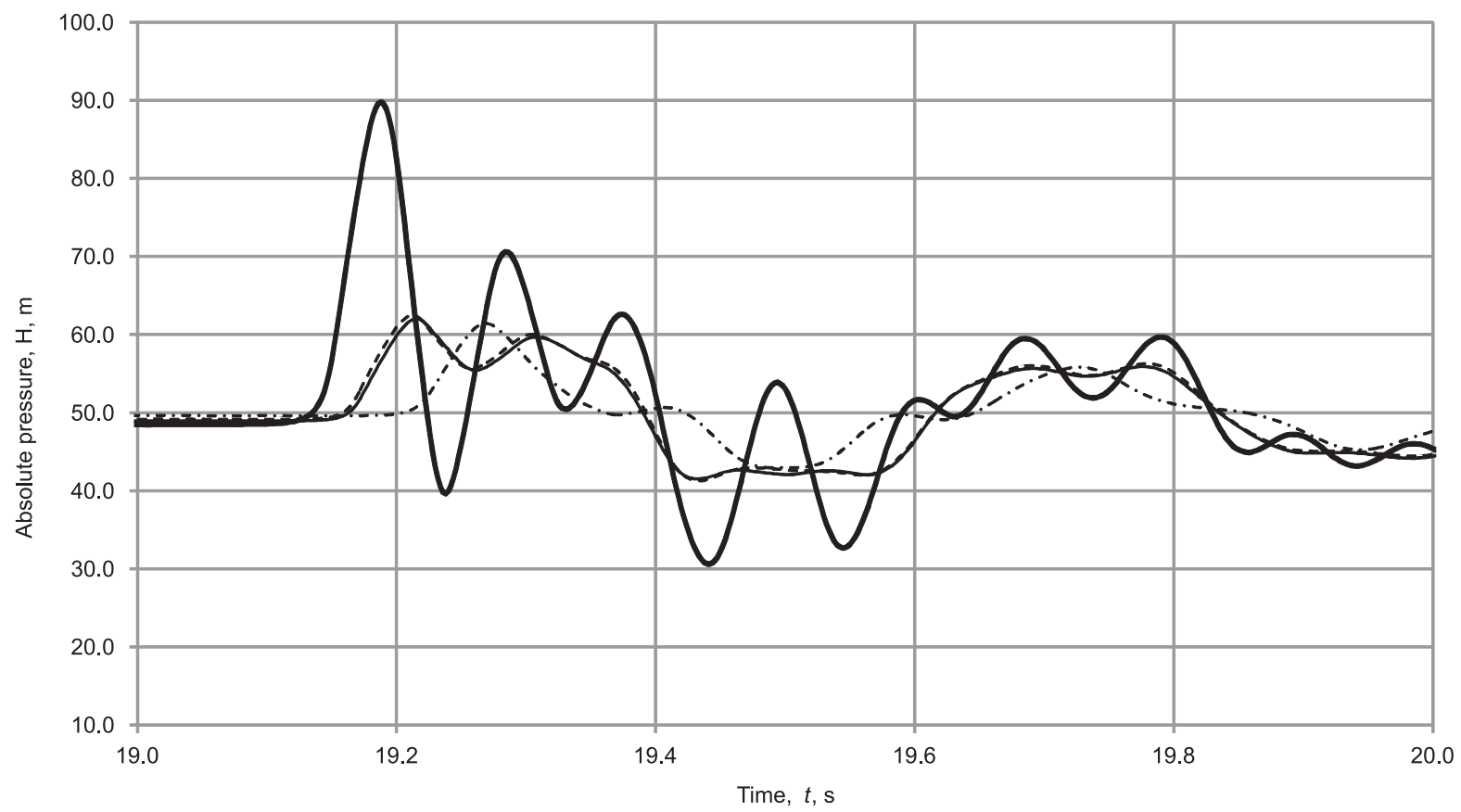

Fig. 7. Pressure variability during the transient pipe flow in pipe made of half of high density polyethylene and half of galvanized steel with total length $L=52.32 \mathrm{~m}$, at an initial pressure of $H_{0}=0.5 \cdot 10^{6} \mathrm{~Pa}$, and an initial speed of $v_{0}=0.4 \mathrm{~m} \cdot \mathrm{s}^{-1}$ 
Table 1 presents the values of the pressure wave velocity determined on the basis of pressure measurements in characteristic cross-sections of the tested pipeline.

Table 1. List of parameters determined for the pressure wave on the basis of empirical research results: $c$ - the pressure wave velocity, $L$ - the length of the pipe

\begin{tabular}{|c|c|c|}
\hline Pipe material $^{1} \quad$ The parameter & $\begin{array}{c}c \\
\mathrm{~m} \cdot \mathrm{s}^{-1}\end{array}$ & $\begin{array}{l}L \\
\mathrm{~m}\end{array}$ \\
\hline steel & 1090 & 52.32 \\
\hline polyethylene & 247 & 52.32 \\
\hline $\begin{array}{l}3 / 4 \text { steel } \\
\text { and } 1 / 4 \text { polyethylene }\end{array}$ & $\begin{array}{c}1308 \\
246\end{array}$ & $\begin{array}{l}39.17 \\
13.15\end{array}$ \\
\hline $\begin{array}{l}1 / 2 \text { steel } \\
\text { and } 1 / 2 \text { polyethylene }\end{array}$ & $\begin{array}{l}1224 \\
245\end{array}$ & $\begin{array}{l}25.30 \\
27.02\end{array}$ \\
\hline $\begin{array}{l}1 / 4 \text { steel } \\
\text { and } 3 / 4 \text { polyethylene }\end{array}$ & $\begin{array}{c}1351 \\
245\end{array}$ & $\begin{array}{l}13.24 \\
39.17\end{array}$ \\
\hline $\begin{array}{l}1 / 4 \text { polyethylene } \\
\text { and } 3 / 4 \text { steel }\end{array}$ & $\begin{array}{c}205 \\
1286\end{array}$ & $\begin{array}{l}13.24 \\
39.39\end{array}$ \\
\hline $\begin{array}{l}1 / 2 \text { polyethylene } \\
\text { and } 1 / 2 \text { steel }\end{array}$ & $\begin{array}{c}219 \\
1142\end{array}$ & $\begin{array}{l}25.30 \\
27.33\end{array}$ \\
\hline $\begin{array}{l}3 / 4 \text { polyethylene } \\
\text { and } 1 / 4 \text { steel }\end{array}$ & $\begin{array}{l}245 \\
426\end{array}$ & $\begin{array}{l}39.17 \\
13.15\end{array}$ \\
\hline
\end{tabular}

Based on the results from table 1, one can notice a manifest influence of both the position of the individual sections relative to the tank, and of their length, on the velocity of the pressure wave created during the water hammer phenomenon. When comparing the values of the pressure wave velocity for pipes made of homogeneous material with the pressure values determined on the basis of formula (5) amounting to, respectively, $1412 \mathrm{~m} \cdot \mathrm{s}^{-1}$ for steel pipe and $333 \mathrm{~m} \cdot \mathrm{s}^{-1}$ for polyethylene pipe, we observe significant differences mainly due to the fact that theoretical formulas do not account for all the factors affecting the speed of the pressure wave (Gietka, 2016). Considering the speed $c$ values for pipes made of non-homogeneous materials, it is evident that in the case of plastic, the position relative to the tank and the valve and the length of the pipe do not have a significant impact on the velocity of the pressure wave, because the latter has similar values to the velocity in pipes made of homogeneous material. In the case where there are short sections of the plastic pipe from the side of the tank, the velocity of the pressure wave in these sections is lower. This is related to the pressure wave duration in this section of the pipe, which is relatively large compared to short sections of steel, and the time of pressure wave persisting in the tank. The situation changes dramatically in the case of a steel pipe, for which both the length and the position relative to the tank and valve affect the speed $c$. It is evident that in almost all cases, for the pipe made of steel, the velocity of the pressure wave is greater than the value for a homogeneous pipe. It is only when the $13.15 \mathrm{~m}$ steel pipe is at the valve that the value is more than two times lower than for the homogeneous pipe. However, if the $13.24 \mathrm{~m}$ steel pipe is located on the side of the tank, the pressure wave velocity is the highest.

Considering the results of pressure measurements for the final cross-section of the presented measurement series (see: Fig. 8), one can notice the obvious impact of the position of individual sections relative to the tank and the valve on the variability of pressure over time. When the polyethylene pipe is on the valve side and the steel pipe is on the side of the tank, then the pressure wave has a similar shape to the pressure wave for a homogeneous plastic pipe. The peak is visible only in the first stage of the wave, and its position depends on the length of the polyethylene segment of the pipe, whereas it is related to the wave reflection at the connecting point of the pipes where the velocity of the pressure wave changes. The situation changes when there is a steel pipe on the valve side and the polyethylene pipe is located on the side of the tank. In that case, a much greater dynamics of the phenomenon is visible due to the overlap of reflected waves at the connection point of the pipes. This results from the difference in velocity of the pressure wave in the tested pipes, as it is much larger in the elastic pipe than in the viscoelastic pipe.

\footnotetext{
1 The sequence of materials in the table is given from the side of the talk, towards the valve.
} 


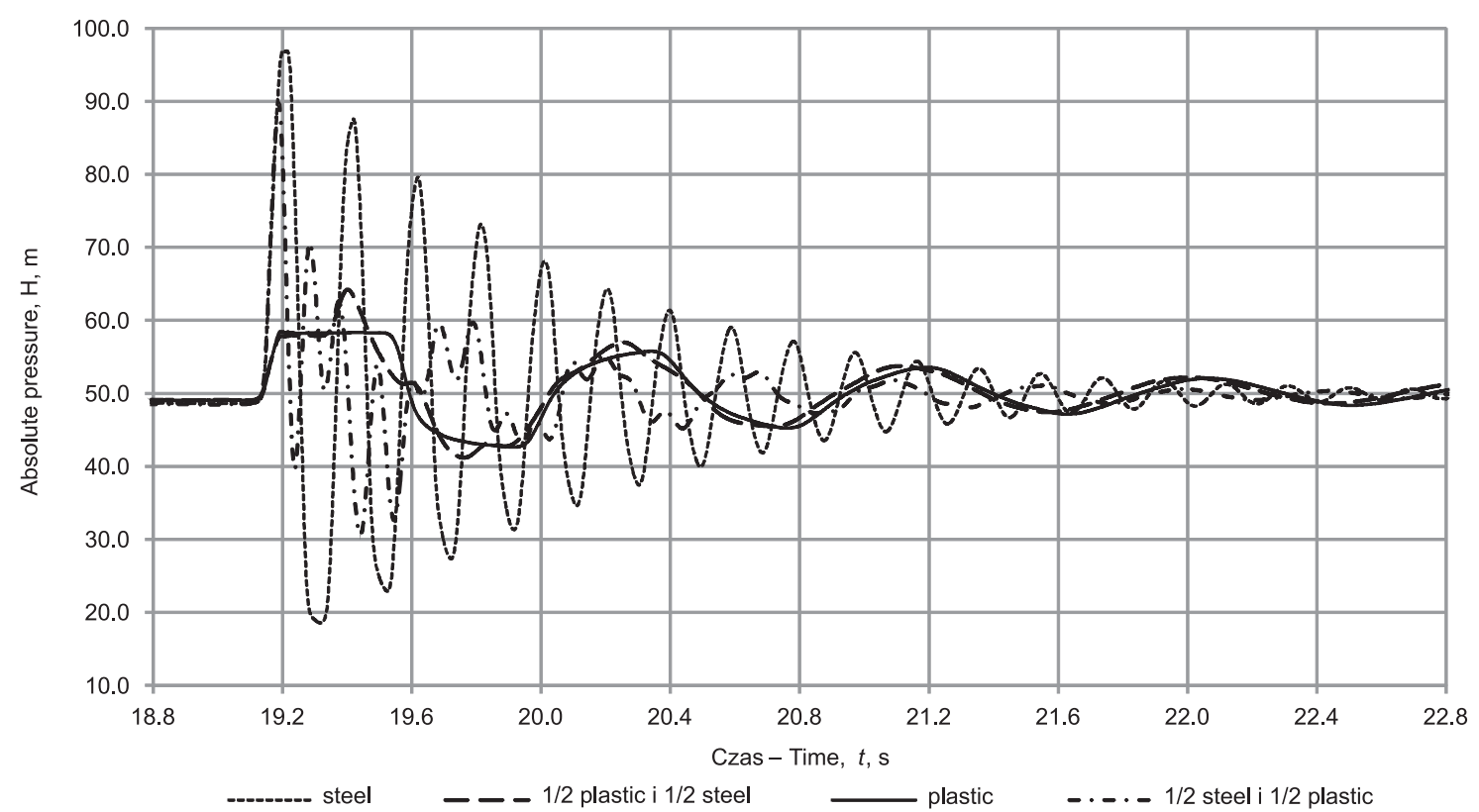

Fig. 8. Pressure variability during the transient pipe flow for the final section

\section{CONCLUSIONS}

From the carried out tests, it is clear that both the length of the pipe and its position relative to the valve and the tank affect the value of the velocity of the pressure wave of the water hammer phenomenon. The lowest speed values occur in the case of the pipe with viscoelastic properties, and the largest occur in the elastic pipe. Connecting pipes with different mechanical properties means that the speed in individual segments is variable, whereas a partial reflection of the pressure wave occurs at the spot of connection. For this reason, the course of the phenomenon in time is different than for pipes made of homogeneous material. Knowing that the plastic section in the installation made of elastic material changes the waveform of the pressure of the water hammer and reduces the wave speed, this solution can be applied in engineering practice whereby the elimination of the negative effects of this phenomenon can be expected, along with a reduction of the maximum pressure increase that occurs in the first period of the pressure wave.

\section{REFERENCES}

Chorzelski, M. (1999). Badania zjawiska uderzenia hydraulicznego w ciągu przewodów o różnej sprężystości ścianki. Prace Naukowe Politechniki Warszawskiej. Uczelniane Centrum Badawcze Energetyki i Ochrony Środowiska, 3, 78-93.

Covas, D., Stoianov, I., Mano, J. F., Ramos, H., Graham, N., Maksimovic, C. (2005). The dynamic effect of pipe-wall viscoelasticity in hydraulic transients. Part II-model development, calibration and verification. Journal of Hydraulic Research, 43(1), 56-70.

Gietka, N. K. (2016). Analiza porównawcza procesów tłumienia i wygładzania fali ciśnienia w trakcie nieustalonego przepływu w rurociągach wykonanych z różnych materiałów. Acta Scientiarum Polonorum Formacio Circumiectus, 15(4), 153-166.

Mitosek, M., Chorzelski, M. (2001). Analiza doświadczalna możliwości stosowania metody odbić i transformacji w ocenie przebiegu uderzenia hydraulicznego w ciagu przewodów o różnej odkształcalności ścianek. Energetyka i ochrona środowiska, (4), 88-100.

Mitosek, M., Chorzelski, M. (2002). Ocena stosowania metody odbić i transformacji w symulowaniu uderzenia hydraulicznego. Prace Naukowe Politechniki Gdańskiej Inżynieria Środowiska, (40), 5-18. 
Mitosek, M., Kodura, A. (2000). Wpływ długości rurociągu na rozpraszanie energii uderzenia hydraulicznego. Prace Naukowe Politechniki Warszawskiej, Inżynieria Środowiska, (32), 63-80.

Mitosek, M., Malesińska, A. (2000). Zastosowanie metody analizy drgań własnych do oceny zjawiska uderzenia hydraulicznego. Prace Naukowe Politechniki Warszawskiej Inżynieria Środowiska, (36), 25-36.

Mitosek, M., Szymkiewicz, R. (2016). Reservoir Influence on Pressure Wave Propagation in Steel Pipes. Journal of Hydraulic Engineering, 142(8).
Weinerowska-Bords, K. (2006). Viscoelastic model of waterhammer in single pipeline - problems and questions. Archives of Hydro-Engineering and Environmental Mechanics, 53(4), 331-351.

Weinerowska-Bords, K. (2015). Alternative Approach to Convolution Term of Viscoelasticity in Equations of Unstady Pipe Flow. Journal of Fluids Engineering, 137(5).

Wylie, E. B., Streeter, V. L. (1987). Fluid Transients. New York: McGraw-Hill.

\section{BADANIA EKSPERYMENTALNE WPŁYWU ZMIANY MATERIAŁU PRZEWODU NA PROPAGACJĘ FALI CIŚNIENIA W TRAKCIE UDERZENIA HYDRAULICZNEGO}

\section{ABSTRAKT}

Zaprezentowano wyniki badań zjawiska uderzenia hydraulicznego w przewodach niejednorodnych materiałowo. Pokazano wpływ zmiany rodzaju materiału przewodu na prędkość rozchodzenia się fali ciśnienia powstałej podczas przepływu nieustalonego w przewodach pod ciśnieniem.

Badane były przewody wykonane ze stali ocynkowanej oraz polietylenu wysokiej gęstości. Pomiarów dokonywano za pomocą tensometrycznych czajników ciśnienia o dużej dokładności pomiarów.

Wyniki pomiarów prędkości fali ciśnienia dla układów przewodów połączonych szeregowo, częściowo z PE-HD i stali ocynkowanej wahają się w granicach od 205 do $247 \mathrm{~m} / \mathrm{s}$ dla polietylenu oraz od 426 do $1351 \mathrm{~m} / \mathrm{s}$ dla stali. Widoczne jest zatem, iż zmiana rodzaju materiału przewodu wpływa w istotny sposób na wartość prędkości fali. Na wartość tej prędkości mają wpływ nie tylko właściwości samego materiału przewodu czy też cieczy, ale także jego długość oraz położenie względem siebie. Widoczne jest, że wartość prędkości w przewodzie polietylenowym nie zmienia się w znaczący sposób w stosunku do sytuacji, kiedy przewód jest jednorodny materiałowo. Sytuacja jest diametralnie różna w przypadku przewodu stalowego, gdzie prędkość fali ciśnienia ulega zmianie wraz z długością przewodu i jego położeniem względem zbiornika. Najmniejsza wartość prędkości w przewodzie sprężystym osiągana jest kiedy znajduje się on od strony zaworu i ma długość jedynie 13,15 m. Największa natomiast jest osiągana kiedy przewód stalowy o długości 13,24 m jest położony od strony zbiornika. Analizując wyniki pomiarów ciśnienia poszczególnych czujników dla przewodu niejednorodnego materiałowo można zauważyć, że w miejscu połączenia dochodzi do częściowego odbicia fali ciśnienia, dlatego zmienność ciśnienia w czasie dla przewodów niejednorodnych materiałowo różni się do zmienności ciśnienia dla przewodu jednorodnego materiałowo.

Słowa kluczowe: uderzenie hydrauliczne, prędkość fali ciśnienia, materiał przewodu, rurociąg sprężysty, rurociag wiskoelastyczny 